\title{
Teachers Perception in Inculcating Islamic Values at Secondary Schools
}

\author{
Muhammad Amin Mt a,1, Azlina Mustaffa b,2,* \\ ${ }^{a}$ Kulliyyah of Education, International Islamic University Malaysia \\ ${ }^{\mathrm{b}}$ Kulliyyah of Education, International Islamic University Malaysia \\ ${ }^{1}$ mohd_amin_mt@yahoo.com; ${ }^{2}$ azlina910@yahoo.com* \\ * corresponding author
}

ARTICLE INFO

Article history

Received 2019-07-10

Revised 2019-07-30

Accepted 2019-08-05

Keywords

Islamic education

inculcating Islamic value

teachers perception

\section{ABSTRACT}

This research intended to explore the challenges in inculcating Islamic values among teachers in selected private secondary schools in the Klang Valley. It aimed to investigate the teachers' perception in inculcating Islamic values in schools. The questionnaire was distributed to 145 teachers from three private Islamic secondary schools in the Klang Valley, namely Al-Amin secondary school, International Islamic Secondary (IIS) School and ADNI Islamic Secondary School. A 5-point Likert scale was used to measure the teachers' perception about the inculcating Islamic values in schools. Descriptive analysis (frequencies and percentages), were utilized in this study. The findings showed that most of the teachers in the three schools in the Klang Valley perceived that they are not inculcating Islamic values into their teaching. The researcher suggested that future research should include additional Islamic schools to compare their methods of teaching Islamic studies, which can also include universities.

This is an open access article under the CC-BY-SA license.

\section{Introduction}

Education is a cumulative process of teaching and learning for transferring and obtaining knowledge. Education is deliberately chosen to influence and assist students with the aim of improving self-faculty, i.e. the physical, moral, spiritual, cognitive, mental, and intellectual aspects of a person, which can gradually empower students to attain the highest level of quality.

Scholars describe for Islamic education, which ramify from it and lead to it. They also transform positively and negatively according to the current religious conditions. It is beneficial to review the general meaning of education from Arabic terms. The word education in Arabic is tarbiyah. [1] Ibn Mandhur maintains in Lisan Al- 'Arab that tarbiyah means "addition up, growth, nourishment, care, and preservation" (Mandhur, 2003, p. 384). According to him, the word tarbiyah is derived from raba al-Shay', rabwan, and riban, which means it increases and grows. Furthermore, Muhamamad Murtadha Azzubaidi (1888) noted that the derivation of the word tarbiyah also came from rabba, not from raba; for instance, it could be said that rabba waladuhu wa al-Sabiyu yurabbihi', which means that "He excellently accomplishes his duties towards his child and handles him until he attains puberty and leaves childhood" (p. 261). (Salleh, 2009; Yasin, 2013) define the concept of education according to three categories. Firstly, the word At-tarbiyya deals with the physical and intellectual development of the individual. Secondly, the word At-ta alim is concerned with teaching and learning conduct. Lastly, the word At-ta adib is concerned with the cultivation of good morals and ethical values. All these concepts are used in explaining the central aim and meaning of Islamic education. According to [3], Islamic education is crucial to Muslims, as it is not only about acquiring 
knowledge, but also enhancing their preparation for the Hereafter (p.234). The research objective of this study is to investigate the teachers' perception about inculcating Islamic values in school.

\section{Statement problem}

In order to emphasis on moral and religious values, teachers should not only transmit the knowledge to students but also inculcate Islamic values. At this point, Tauhidi (2001) states that "the teaching of Islamic education should be emphasized on the teaching about "being a Muslim" not only teaching about "Islam". In short, it is one of teachers' responsibilities to inculcate Islamic values to students in order for the students to be morally good, thereby enabling them to further contribute to the betterment of the nation and Muslim society at large.

Effective teaching method of Islamic values is facing several challenges as teachers struggle to make teaching value-based. Many teachers in Islamic schools are facing different challenges in inculcating Islamic values. Normatively, teachers are required to conduct teaching and learning passionately and professionally. Moreover, Islamic education not only requires Muslim teachers to teach students professionally, but also persuades them to be committed to Islam by inculcating Islamic moral values. However, the process of inculcating Islamic values is not without constraints. For instance, examining the problems faced by the teachers of Islamic Religious Knowledge subject in secondary schools, [5] set at least five challenges that perceived by the teachers of Islamic Religious Knowledge subject in inculcating Islamic values.

From the above points, since Islamic values inculcation is perceived as the core of Islamic education, inculcating Islamic values should also be seen as the core of teaching and learning in Islamic education. Therefore, this study is aimed at identifying teachers' perception in inculcating Islamic values in secondary schools.

\section{Method}

The population of this study is all teachers in selected private secondary schools, namely AlAmin secondary school, International Islamic Secondary (IIS) School and ADNI Islamic Secondary School in Klang Valley. The reason for selecting those three schools is that their philosophy is quite similar in flourishing Islamic values to students. The information and the complete list of the population are based on the database provide by the schools. The population of teachers in the three secondary schools consists of 145 teachers. The following table shows the total number of teachers from the three selected schools.

Table 1. Total Population of Teachers from the Three Secondary Schools

\begin{tabular}{cccc}
\hline School & Male & Female & Total \\
\hline Al-Amin Islamic secondary school & 20 & 40 & 60 \\
International Islamic Secondary School & 17 & 22 & 39 \\
ADNI Islamic Secondary School & 16 & 30 & 46 \\
\hline Total & $\mathbf{5 3}$ & $\mathbf{9 2}$ & $\mathbf{1 4 5}$ \\
\hline
\end{tabular}

a. Sources: Principal of Al-Amin Islamic Secondary School, Principal of International Islamic Secondary School and Principal Adni Islamic secondary School (2017).

The population consists of all teachers teaching different subjects in the selected schools under study. Due to the small size of the population, this study is going to collect the responses from the whole population, regardless of their demographical background. Therefore, in this study, taking the responses from the whole population will provide rich information which results in deriving fruitful opinions from the teachers, especially with respect to the challenges of inculcating values perceived in teaching different subjects.

\section{Results and Discussion}

What are the teachers' perceptions about inculcating Islamic values in school? There is currently a high level of interest in reviving Islamic education in Muslim societies. Specifically, in Southeast Asian Muslim countries, Islamic education is propagated to solve youth moral decadences [6]. An 
effort such as the integrating of educational methods in the context of Malaysia has received the attention of researchers, who have recommended that knowledge should be learnt together with moral values (Halabi, 2015, p.1). From a Malaysian perspective, Islamic Religious Knowledge as a stand-alone subject is formulated to bring Islamic teachings into the formal school curriculum. Additionally, in the context of Malaysia, Sahari and Langgulung (1999) maintain that the formulation of Islamic education is centred upon the National Education Philosophy, the curriculum at any level, textbooks, and the teacher training programmes. However, "...the implementation of Islamic Religious Knowledge is far from satisfactory" (Sahari \& Langgulung, 1998, p.71). Such of these efforts and challenges almost align the core of Islamic education implementation all over Muslim societies.

The failures in uplifting students' attitude implicate the satisfactoriness of Islamic Religious Knowledge as a stand-alone subject in developing students' good behaviour. There are at least four factors analysed by Sahari and Langgulung (1999) that affect the pupils' attitude towards Islamic Religious Knowledge, which correspond to the reasons why Islamic Religious Knowledge does not satisfactorily shape pupils' behaviour. Those four factors are teaching method, teacher characteristics, textbooks, and curriculum structure. Their study records a respondent's comment on teacher characteristic factor as "...a substantial majority of the respondents perceived that the behaviours of other teachers (87.8\%) and that of Islamic Religious Teachers $(86.0 \%)$ which do not comply with Islamic values..." (Sahari \& Langgulung, 1999, p.75).

Accordingly, with regard to the values that the teachers should inculcate students with, it is not only teacher characteristic factor, but also the other three factors, namely teaching method, textbooks, and curriculum structure, which should support the values inculcation. That is because the inculcation of values is almost the core of Islamic education. For example, textbooks provided to students should be authored with contents that properly support values inculcation. Moreover, good textbooks will not only become the source of knowledge for the students, but also the source of values standards to which students can refer. Additionally, teachers also play a vital role in improving methods of teaching to inculcate students with Islamic values, so as to ensure that they can apply these values both at home and school.

Apart from that, the aim of education in Islam should be to develop Islamic ethics, moral values, and spirituality, besides physical, emotional, and cognitive prowess. In other words, the backbone of Islamic education is made up of spiritual development and the upgrading of moral values. According to Al-Attas (1993), justice and goodness are important in seeking knowledge for every person as a man or individual, as (cited in Othman, 2006, p.18). In addition to that, Halim Tamuri, Yusof Othman, Dakir, Munawar Ismail, and Stapa (2013) confirm that based on the Islamic Educational Philosophy, the key objective of education is to create attitudes, while the key purpose of education is to form attitudes, abilities skills, character and the way of life as a slave of Allah who carries out tasks with the aim of upgrading oneself, society, the environment and nation towards the attainment of goodness in this life as well as in the Hereafter (akhirah). The essence of spirituality and moral values among the Muslims is, therefore, to produce a balanced personality who is not only responsible for his whims and caprices, but utilizes all material and non-material resources in showing the servility of obedience to the Supreme God, the Lord the Universe.

The contemporary Muslims have witnessed a dramatic interpolation of Islamic values systems with non-Islamic values, which has distorted the holistic development of man. The foreign cultures which are imported into Muslim nations have corrupted the Islamic culture and eroded the values system among Muslims [10]. Since the very first Muslim Conference in 1977, development and enhancement of the Islamic value system have been re-raised by Muslim intellectuals. Besides that, the whole discourse and resolutions of the conference were based on the holistic curriculum in promoting intellectual, spiritual, social, cultural, physical, moral etc. development of the Muslims [11]. Those spirits of reviving Islamic values in educational settings seems to be inspired by verses from the holy Quran. In fact, the holy Quran has instructed the believers to provide moral and spiritual training for their personality development. For example, Allah says in Surah At-Tahrim (66:6); "O you who believe! Save yourselves and your family from a fire whose fuel is men and stones; over it are angels stern and strong, they do not disobey Allah in what He commands them, and do as they are commanded". 
Based on the above quoted verse, it is understandable that belief, coupled with moral uprightness, is an underlying factors through which the believers save themselves from the torment of hellfire in the hereafter [12]. It is irrefutable that the issue of Islamic values is not an issue of 'what is', but rather an issue of 'what ought to be'. This is why deciding on right and wrong according to Islamic perspectives is reserved only for Allah. Madkur (1987) has pinpointed the views of such notable Muslim scholars as al-Ghazali, Ibn-Jama'ah and Hatim al-Assam on the Islamic educational system. They believe that Islamic education should stress Islamic values which motivate learners to do righteous and virtuous deeds. In this regard, the teacher is the most effective factor in the inculcation of Islamic values in students. Yusuf Qardawi (1980) stated that a righteous and proficient teacher can influence students and compensate for deficiencies in curriculum and books.

In Malaysia, since Islam is the official religion of this country, Islamic education has been taught formally in the national educational system. However, it is worth mentioning that the implementation of Islamic education in this country has undergone several challenges to place itself in the current national education system [14].

The results of this study, which is investigates the teachers' perception towards inculcating Islamic values in school. The researcher used descriptive statistics to analyse the teachers' perceptions about inculcating Islamic values among teachers of the three selected Islamic schools. Table 1 below presents the Mean scores and Standard deviation of the results.

Table 2. Presents the Means Scores and Standard Deviation of the Results

\begin{tabular}{|c|c|c|c|c|c|}
\hline \multirow[t]{3}{*}{ No } & \multirow[t]{3}{*}{ Items } & \multicolumn{3}{|c|}{ Percentage/Frequency } & \multirow{3}{*}{$\begin{array}{c}\text { Means \& } \\
\text { SD }\end{array}$} \\
\hline & & $\boldsymbol{A}$ & $D$ & & \\
\hline & & & & $N(\%)$ & \\
\hline \multirow[t]{2}{*}{1} & I make an effort in inculcating Islamic values during & 0.9 & 6.6 & 92.5 & $\mathrm{M}=2.915$ \\
\hline & teaching and learning. & (1) & (7) & $(98)$ & $\mathrm{SD}=.312$ \\
\hline \multirow[t]{2}{*}{2} & I believe that Islamic values are important to students. & 0.9 & 2.8 & 96.2 & $\mathrm{M}=2.952$ \\
\hline & & (1) & (3) & $(102)$ & $\mathrm{SD}=.253$ \\
\hline \multirow[t]{2}{*}{3} & I believe that I can improve students' character by & 1.9 & 3.8 & 94.3 & $\mathrm{M}=2.924$ \\
\hline & inculcating Islamic values. & (2) & (4) & $(100)$ & $\mathrm{SD}=.329$ \\
\hline \multirow[t]{2}{*}{4} & I think that I can inculcate Islamic values at every possible & 0.9 & 11.3 & 87.7 & $\mathrm{M}=2.867$ \\
\hline & opportunity in my class. & (1) & $(12)$ & (93) & $\mathrm{SD}=.367$ \\
\hline \multirow[t]{2}{*}{5} & I think that it is my duty to inculcate Islamic values into & 0.9 & 5.7 & 93.4 & $\mathrm{M}=2.952$ \\
\hline & students. & (1) & (6) & (99) & $\mathrm{SD}=.299$ \\
\hline \multirow[t]{2}{*}{6} & I think that I need to inculcate Islamic values in my & 1.9 & 0.9 & 97.2 & $\mathrm{M}=2.952$ \\
\hline & teaching. & (2) & (1) & $(103)$ & $\mathrm{SD}=.288$ \\
\hline \multirow[t]{2}{*}{7} & I think that teacher in school should be able to inculcate & 0.0 & 5.7 & 94.3 & $\mathrm{M}=2.993$ \\
\hline & Islamic values into students. & $(0)$ & $(6)$ & $(100)$ & $\mathrm{SD}=232$ \\
\hline
\end{tabular}

Table 1 provides information on the details of the frequency and percentage for each item involved in teachers' perception on inculcating Islamic values in their teaching in Islamic Schools. The results show that most teachers, more specifically $95 \%$ of the teachers, who participated in this study perceived that they are not sure of their inculcating Islamic values in their teaching at school, while very few agreed and disagreed. For instance, in item 6, (97.2 \%) of teachers were not sure whether they needed to inculcate Islamic values in their teaching, while 0.9 and 1.9 respectively disagreed or agreed with the item. Moreover, in (Item 2), the vast number of the teachers (96.2\%) was not sure whether or not Islamic values are important to students, compared to 0.9 and 2.8 , who respectively agreed or disagreed with the statement. Thus, it can be concluded from the above table that the majority of the participants were not sure of inculcating Islamic values during teaching and learning.

The majority of the participants were not sure of their inculcating Islamic values during teaching and learning. Although some of the teachers' believed in their inculcating of Islamic values into their teaching, other teachers did not agree with the statements. In this case, it can be seen that the majority of teachers are not sure of the methods to inculcate Islamic values. Although memorization is the main aspect of the method of teaching Islamic studies, memorization without understanding the content about what has been memorized is not encouraged in Islam. This is why when one opens the Holy Qur'an from the first page to the last page you can observe a lot of verses encouraging 
people to think, to reflect, to do tadabbur, to understand, to ask questions, to read and to teach. In the Qur'an (2:30), Allah mentions, "And [mention, O Muhammad], when your Lord said to the angels, "Indeed, I will make upon the earth a successive authority." They said, "Will you place upon it one who causes corruption therein and sheds blood, while we declare Your praise and sanctify You?" Allah said, "Indeed, I know that which you do not know".

Interactive group discussions would be the preferred method to be used by many teachers as a teaching strategy in the class (Sacdalan, et al., 2002). Team learning and student-led discussions would foster greater participation, self-confidence and leadership ability, as well as encourage students' performance outcomes (Rosle et al., 2009). Discussion methods enable students to recall facts or be engaged in lower order thinking skills. Hence, in comparison to traditional lecture-based methods, group discussion method shows positive outcomes in terms of students' participation in the classroom (Carpenter, 2006).

\section{Conclusion}

Teaching Islamic values and inculcating them can help students to develop their minds rapidly and to understand the changing world around them. Furthermore, it also helps students to solve everyday problems that they face in their lives by thinking positively, critically and respecting different ideas among their colleagues.

The present study's limitation is that the method of teaching Islamic studies was only investigated among secondary students in three selected Islamic schools. However, future research should include additional Islamic schools to compare their methods of teaching Islamic studies, which can also include universities in future research. In addition to this, future research could also include having students discuss the methods of teaching Islamic values. Investigating approaches to teaching Islamic values is necessary to improve the teaching styles of teachers teaching Islamic values, where future studies should consider the effective means of teaching values.

\section{References}

[1] I. Mandhur, Lisan al-'Arab (Language of the Arabs). Riyadh: Dar 'Alam al-Kutub, 2003.

[2] M. J. Salleh, "the Integrated Islamic Education: Principles and Needs for Thematic Approaches," Singapore Islam. Educ. Syst., pp. 1-13, 2009.

[3] R. Hashim, Educational Dualism In Malaysia; Implications for Theory and Practice. Kuala Lumpur: The Other Press, 2004.

[4] D. Tauhidi, "The Tarbiyah Project: An Overview, Towards A Renewed Vision of Islamic Education." 2001.

[5] D. H. Nur-Ashikin, "Problems in Teaching Islamic Religious Knowledge: A Survey on Teachers' Perceptions in Secondary Schools in Negara Brunei Darussalam," International Islamic University Malaysia, 2003.

[6] Y. J. Halabi, "Inculcating Islamic Values in Teaching Mathematics from Teachers and Pupil's Perspectives: A Case Study,” International Islamci University Malaysia, 2015.

[7] M. N. Sahari and H. Langgulung, "Reasons for School Children's Poor Attitude towards Islamic Education: A pilot Inquiry," J. Pendidik. Islam, vol. 8, no. 3, pp. 69-83, 1999.

[8] K. Othman, "Teachers ' Conceptions and Practice of Islamization of Knowledge in the Teaching of English : A Case Study,” International Islamic University Malaysia, 2006.

[9] A. Halim Tamuri, M. Yusof Othman, J. Dakir, A. Munawar Ismail, and Z. Stapa, "Religious education and ethical attitude of Muslim adolescents in Malaysia," Multicult. Educ. Technol. J., vol. 7, no. 4, pp. 257-274, 2013.

[10] I. R. Al-faruqi, Islamization of knowledge: Problems, Principles and Prospective; Islam Source and Purpose of Knowledge (Islamization of Knowledge Series), 5th ed. Virginia USA: International Institute of Islamic Thought, 1988. 
[11]M. F. R. Holori, "Teachers ' Attitude and Approaches in the Inculcation of Islamic Values in Teaching: A Study Of International Islamic School Teachers," International Islamic University Malaysia, 2013.

[12]Z. Alam, Islamic Education Theory \& Practice. New Delhi: Adam, 2003.

[13] A. A. Madkur, Minhajut-tarbiyyah al-Islamiyyah: Usuluhu wa tațbiqatihi. Kuwait: Maktabatul Falah, 1987.

[14]Z. Mustafa, "Factors Affecting Students ' Interest in Learning Islamic Education: A Case Study in A Selected Secondary School in The District of Gombak," 2010. 